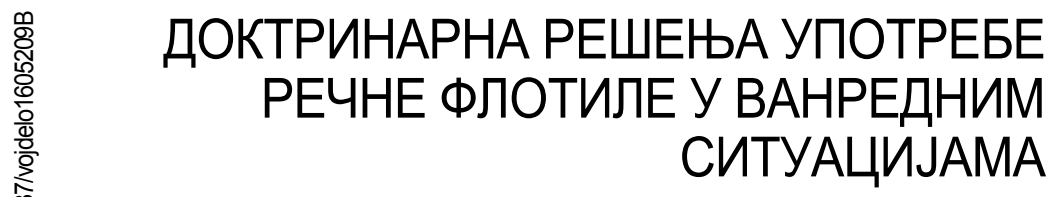

\author{
Шерифф Б. Бајрами \\ Војска Србије, Копнена војска, Речна флотила \\ Раде В. Славковић \\ Универзитет одбране у Београду, Војна академија
} сновна намена Војске Србије јесте одбрана земље од оружа-
ног угрожавања споља и дефинисана је Уставом Републике Србије. Међутим, све учесталија појава елементарних непогода захтева, поред уобичајених снага, активну употребу јединица Војске Србије у пружању помоћи цивилним органима власти у заједничкој борби против разарајућих последица проузрокованих јаким земљотресима, великим поплавама, сушама и снежним падавинама. Важно место у трећој мисији Војске Србије, нарочито када је реч о пружању помоћи цивилним властима у случају великих поплава, заузима Речна фрлотила са свим својим људским, материјалним и организационим капацитетима. Речна флотила, као саставни део Војске Србије, успешно је реализовала задатке заштите и спасавања људи, материјалних добара и животне средине током претходно проглашених ванредних ситуација на територији Републике Србије. Међутим, стечена искуства указују на потребу даљег развоја оперативних способности која су у фрункцији извођења неборбених операција - подршка цивилним властима у супротстављању претњама безбедности. Унапређење и изградњу оперативних способности могуће је планирати преко чинилаца развоја и то: доктрине, организације, обуке, опремања и финансирања Речне фрлотиле.

Кључне речи: Речна фрлотила, ванредна ситуација, доктрина, обука, опремање и финансирање

Увод

$\boldsymbol{K}$ атастрофални земљотреси, суше и велике поплаве стални су безбедносни ризици за Републику Србију. Борба против елементарних непогода, чије се последице испољавају на све сфере друштвеног живота, изискује ангажовање многобројних државних и друштвених организација у области заштите и спасавања. Све већи број субјеката који се баве овом проблематиком намеће потребу за унапређењем и усклађивањем њихових функција у јединствен и синергичан одговор како би њихова употреба у ванредним ситуацијама била што ефикаснија и сврсисходнија. 
Данас је евидентан друштвени, економски и безбедносни значај унутрашњих пловних путева, а с тим и улога речних јединица да, у садејству са осталим јединицама Копнене војске, штити интересе Републике Србије на рекама, језерима, каналима и другим текућим и стајаћим водама. Речна флотила као саставни део Копнене војске представља неизбежан субјекат у заштити и спасавању становништва, животне средине и друштва у целини током различитих природних непогода, а нарочито када је реч о ванредним ситуацијама узрокованим великим поплавама. Дефинисање мера за унапређење оперативних способности Речне фрлотиле за такву њену употребу јесте основни циљ овог рада.

\section{Ванредне ситуације}

Данас се свака држава суочава са многобројним изазовима, ризицима и опасностима од акцидената, удеса, хаварија, природних катастрофа и других облика разорног деловања на човека, животну средину и друштво у целини. Један од проблема који отежава успешно и ефикасно функционисање свих субјеката у заштити и спасавању људи и материјалних добара јесте, поред осталог, и јасно теоријско одређење појма „ванредна ситуација”. Учестала, непредвидива и разорна деловања природних непогода, техничко-технолошких несрећа и других облика угрожавања намеће потребу да се појам „ванредна ситуација”, као правни инструмент за којим држава посеже у ситуацијама када су угрожени основни услови за живот и рад, јасно и прецизно дефинише.

\section{Појам ванредних ситуација}

Устав Републике Србије, као основни и највиши правни акт једне државе, не препознаје појам „ванредна ситуација” већ искључиво ванредно и ратно стање. Закон о одбрани много прецизније од Устава обрађује поменута два стања, док се појам „ванредна ситуација” у Закону о ванредној ситуацији коначно препознаје и дефинише као „стање када су ризици и претње или последице катастрофа, ванредних догађаја и других опасности по становништво, животну средину и материјална добра таквог обима и интензитета да њихов настанак или последице није могуће спречити или отклонити редовним деловањем надлежних органа и служби, због чега је за њихово ублажавање и отклањање неопходно употребити посебне мере, снаге и средства уз појачан режим рада".

У страној стручној литератури могу се пронаћи и другачије дефиниције појма „ванредна ситуација”. Тако, на пример, у англоамеричкој литератури користи се термин „state of emergency”. Његово значење се, по правилу, везује за ванредно стање, али са донекле специфичном и ужом садржином. Под овим термином првенствено се подразумева стање које се уводи због елементарних непогода које

\footnotetext{
${ }^{1}$ Устав РС, „Службени гласник РС”, број 98/06, члан 200-201.

2 Закон о ванредним ситуацијама, „Службени гласник РС”, бр. 111/09 и 92/11, члан 8.
} 
прете да угрозе нормално функционисање живота на делу територије или на целој територији неке државе. То јасно потврђује и New Jersey State law (N.J.S.A. App. A, р. 9-37) који дозвољава гувернеру државе да прогласи ванредно стање у време великих временских непогода и природних катастрофа. Овакво решење држава користи као средство за брзо реаговање на потребе грађана, ангажујући додатно људство, возила и друга средства потребна за адекватан одговор на инцидент. ${ }^{3}$

У руској литератури посебно се издваја термин „чрезвычайная ситуация” - ванредна, изванредна, изузетна ситуација. „Чрезвычайная ситуация” је стање у којој је дошло до нарушавања нормалних услова живота и рада у објектима или на одређеној територији, изазваних хаваријом, елементарном непогодом, катастрофом, еколошким акцидентом, епидемијом и слично, а могу довести до људских и материјалних губитака, нанети штету здрављу људи или природи и окружењу, значајне материјалне губитке и нарушавање живота и рада људи.

За разлику од већине других држава, ${ }^{5}$ у Русији је 1994. године уведено посебно Министарство за ванредне ситуације (Министарство по чрезвычайным ситуациям), које је задужено за послове цивилне заштите и отклањање последица природних катастрофра. Један од докумената Министарства, под називом „Основи заштите становништва и територије у кризним ситуацијама ”, ванредну ситуацију дефинише као „скуп ванредних услова и фактора који су се створили у одговарајућој зони као резултат ванредног догађаја". ${ }^{\circ}$

Руски професор Мастрјуков под ванредном ситуацијом подразумева ону у којој на одређеној територији или акваторији долази до нарушавања нормалних услова за живот и рад људи, угрожава се њихов живот и здравље, наноси штета имовини становништва, националној привреди и животној средини.

Стојановић Р. сматра да „када друштво редовним активностима (превентивним, оперативним и одржавањем) не може да спречи, умањи и отклони последице изазване опасностима, оне добијају карактер ванредних ситуација“.

На основу наведених дефиниција може се закључити да појам „ванредна ситуација", у ширем смислу, подразумева изненадан и јединствен догађај који изазива поремећај редовних друштвених процеса и појава, знатно утичући на животе људи, имовину и природну средину, односно, као фактор нестабилности, доводи до дисфункције постојећег друштвеног система, док се, у ужем смислу, под ванредном ситуацијом подразумева стање нарушавања живота и здравља људи, причињавање

\footnotetext{
${ }^{3}$ Аврамовић, Д., Млађан, Д.: „Ванредно стање и ванредна ситуација - компаративни терминолошки и садржински аспекти ", Теме - часопис за друштвене науке, Универзитет у Нишу, број 02, 2014, стр. 770.

${ }^{4}$ Калюжный, Е. А., Михайлова, С. В., Напреев, С. Г. \& Маслова, В. Ю.: Безопасность изнедеятельности, АГПИ, Арзамас, 2012, стр. 16.

${ }^{5}$ Државни органи задужени за проблеме насталих пре, током и након ванредне ситуације углавном су, у организацијском смислу, смештени унутар МО или Министарства унутрашњих послова.

${ }^{6}$ Млађан, Д. и Кекић, Д.: „Ванредна ситуација - прилог концептуалном одређењу безбедности ”, НБП - Журнал за криминалистику и право, бр. 3, Београд, 2007, стр. 61- 83.

${ }^{7}$ Мастрјуков, Б. С.: Безопасность в чрезвичайных ситуациях, Издательский центр Ацадемиа, Москва, 2004, стр. 11.

${ }^{8}$ Стојановић, Р.: Заштита и спасавање људи и материјалних добара у ванредним ситуацијама, Војноиздавачки завод, Београд, 1984, стр. 8.
} 
штете на материјалним добрима и угрожавање животне средине услед дејства елементарних непогода, техничко-технолошких несрећа, као и несрећа насталих ратним разарањима и тероризмом. Немогућност спречавања, ублажавања и отклањања последица услед деловања наведених опасности редовним функционисањем система основни је разлог због којег држава прелази на ванредан начин организовања одређених субјеката и посебан режим функционисања система, који подразумева ангажовање великих материјалних и људских потенцијала.

\section{Класифрикација ванредних ситуација}

Класификација, као научни метод, омогућава циљно оријентисан поредак посматраних феномена путем позивања на једно или више обележја, која се могу разликовати. ${ }^{9}$ Узимајући у обзир претходно терминолошко објашњење појма „ванредна ситуација", а у односу на узроке настанка, могућа је подела на: ванредне ситуације узроковане елементарним непогодама, техничко-технолошким и ратним опасностима. ${ }^{10}$

Елементарне непогоде су појаве настале деловањем природних сила које доводе до прекида редовног живота и рада људи, узрокујући жртве и велику материјалну штету, превазилазећи редовне способности заједнице у адекватном супротстављању и отклањању последице. Манифестовање природних сила огледа се кроз поплаве, цунамије, суше, потресе, снежне мећаве, ветрове орканске и олујне јачине, одроњавање и клизање тла, пожаре, вулканске ерупције и друге појаве.

Елементарна непогода се законским одредбама дефинише као: „(...) догађај хидрометеоролошког, геолошког или биолошког порекла, проузрокован деловањем природних сила, као што су: земљотрес, поплава, бујица, олуја, јаке кише, атмосферска пражњења, град, суша, одроњавање или клизање земљишта, снежни наноси и лавина, екстремне температуре ваздуха, нагомилавање леда на водотоку, епидемија заразних болести, епидемија сточних заразних болести и појава штеточина и друге природне појаве већих размера које могу да угрозе здравље и живот људи или проузрокују штету већег обима".

Техничко-технолошке опасности представљају изненадни и неконтролисани догађај или низ догађаја који је измакао контроли приликом управљања одређеним средствима за рад и приликом поступања са опасним материјама у производњи, употреби, транспорту, промету, преради, складиштењу и одлагању, као што су пожар, експлозија, хаварија, саобраћајни удес у друмском, речном, железничком и авио- саобраћају, удес у рудницима и тунелима, застој рада жичара за транспорт људи, рушење брана, хаварија на електроенергетским, нафтним и гасним постројењима, акциденти при руковању радиоактивним и нуклеарним материјама, а чије по-

\footnotetext{
${ }^{9}$ Петровић, Г.: Логика, Завод за уџбенике и наставна средства, Београд, 1990, стр. 145.

${ }^{10}$ Преузето из Byrne, B. with Baden, S.: Gender, emergencies and humanitarian assistance, report commissioned by the WID Desk, European Commission, Directorate General for Development, Brussels, 1995.

11 Закон о ванредним ситуацијама PC, „Службени гласник PC”, бр. 111/2009, члан 8, тачка 3.
} 
следице угрожавају безбедност и живот људи, материјална добра и животну средину. ${ }^{12}$ Техничко-технолошке несреће настају услед дисфункције техничко-технолошких процеса насталих због кварова на склоповима и истеклих ресурса одређених делова, намерним или случајним деловањем човека, као и због утицаја природних катастрофра.

Ратне опасности јесу последица оружаног сукоба држава, војно-политичких савеза или различитих друштвених снага унутар једне земље у којима се примењује насиље и борбена дејства ради остваривања политичких, економских и војних циљева. Такође, пре отпочињања борбених дејстава постоје опасности од настајања ванредне ситуације применом различитих координираних мера и поступака (политичких, дипломатских, привредних, обавештајно-субверзивних, терористичких и др.) од стране држава потенцијалних агресора према држави будућој жртви агресије. Применом мера и поступака из комплекса специјалног и психолошког рата из предратног мирнодопског периода заоштравају се односи између две и више земаља, што представља увод у оружану агресију и стварање повољних услова за њено успешно извођење. Другим речима, ове мере и поступци директно проузрокују настанак ванредне ситуације, која се објавом рата и почетком борбених дејстава још више усложава. ${ }^{13}$

Може се закључити да појам и класификација ванредних ситуација опредељују, пре свега, различите врсте опасности, које угрожавају безбедност и које, узроковане дејством природе или делатношћу људског фактора, могу да доведу до ванредне ситуације на одређеној територији. Према томе, када се редовним активностима (превентивним, оперативним и другим) не могу спречити и отклонити последице изазване опасностима, онда стања опасности добијају карактер ванредне ситуације.

\section{Доктринарна опредељења о употреби Војске Србије у ванредним ситуацијама}

Основна намена Војске Србије јесте одбрана земље од оружаног угрожавања споља, а дефинисана је Уставом Републике Србије. ${ }^{14}$ Међутим, све учесталија појава елементарних непогода захтева, поред уобичајених снага, активну употребу јединица Војске Србије у пружању помоћи цивилним органима власти у заједничкој борби против разарајућих последица проузрокованих јаким земљотресима, великим поплавама, сушама и снежним падавинама. Начин и услови под којима се Војска Србије припрема и користи у подршци цивилним властима у случају елементарних непогода, техничко-технолошких и других несрећа дефинисани су у доктринарним документима различитог хијерархијског нивоа.

\footnotetext{
12 Закон о ванредним ситуацијама, „Службени гласник РС”, бр. 111/09 и 92/11, члан 8, тачка 4.

${ }^{13}$ Катарина, Ш: Ванредне ситуације, Девета школа реформе сектора безбедности, ISAC Found, Београд, 2007, стр. 146.

${ }^{14}$ Устав Републике Србије, „Службени гласник РС”, број 98/06, члан 139-141.
} 


\section{Доктрина Војске Србије}

Доктрином Војске Србије, највишим доктринарним документом, дефинисана су општа опредељења о војној делатности, организовању, припремама, употреби и обезбеђењу Војске Србије у миру, ратном и ванредном стању. Разрађују се утврђени ставови за изградњу професионалне и ефикасне Војске Србије, материјално и финансијски одрживе, интероперабилне, модерно опремљене и оспособљене за реализацију мисија и задатака. ${ }^{15}$ Додељеним мисијама и задацима, наведеним у Доктрини Војске Србије, држава јасно дефинише своја очекивања и захтеве према Војсци. Њиховом реализацијом задовољава се основна потреба државе за успешном одбраном од оружаних претњи споља, изградња и очување мира у региону и свету, као и потреба за ефикасном борбом у супротстављању савременим претњама безбедности.

Одбрана територије Републике Србије од оружане претње споља представља основну друштвену улогу Војске Србије. Међутим, Војска Србије, као један од основних елемената система одбране чија опремљеност и оспособљеност представља основну снага друштва, налази своје место и у подршци цивилним властима приликом заштите и спасавања људи, материјалних добара и животне средине. Реализацијом задатака у оквиру пружања помоћи цивилним органима власти (слика 1) у ситуацијама интензивног утицаја елементарних непогода, Војска Србије даје одлучујући допринос у свеобухаватној борби друштва у ванредним ситуацијама.

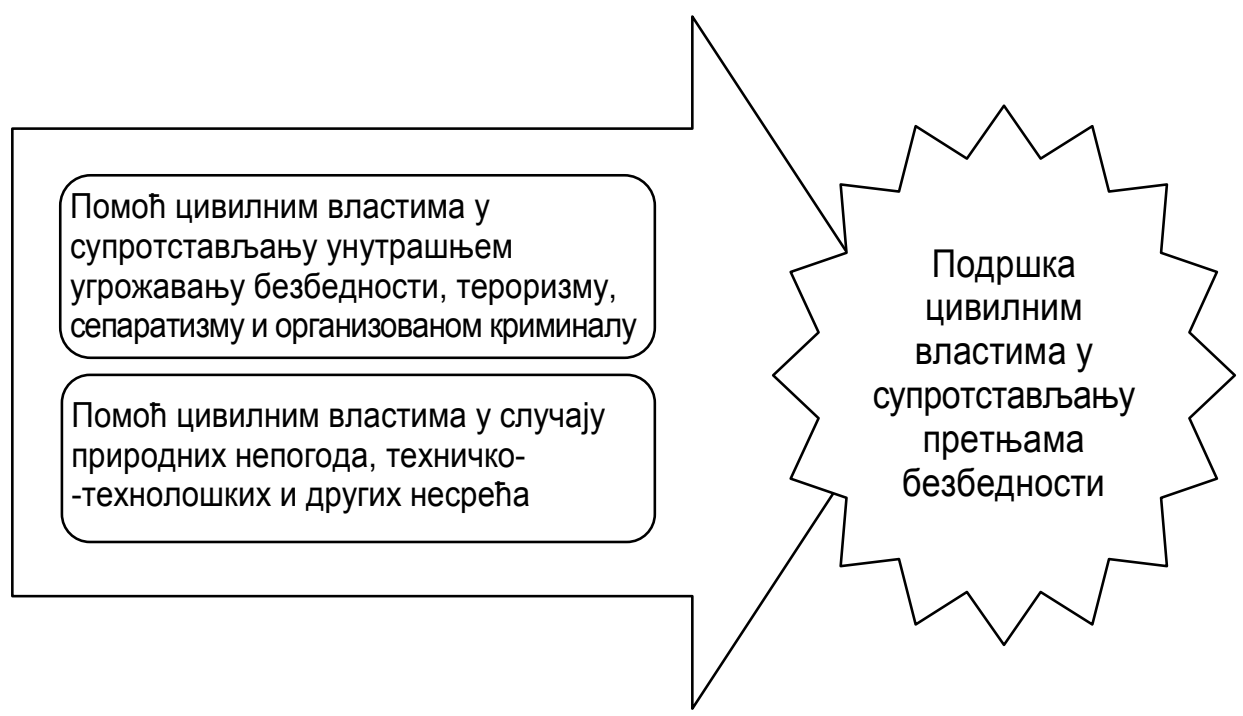

Слика 1 - Шематски приказ треће мисије Војске Србије

\footnotetext{
${ }^{15}$ Доктрина Војске Србије, Медија центар „Одбрана”, Београд, стр. 9.
} 
Учесталост проглашења ванредних ситуација и употреба Војске Србије у условима све комплекснијих и динамичнијих безбедносних изазова, ризика и претњи усмерених према не војним циљевима, где је, по правилу, најугроженије становништво, захтева правилну примену доктринарних решења употребе Војске Србије у њеној трећој мисији - пружање подршке цивилним властима у супротстављању неоружаним претњама безбедности, попут природних непогода, техничко-технолошких и других несрећа ради заштите и спасавања живота људи, материјалних добара и животне средине. Основним доктринарним решењима, наведеним у Доктрини Војске Србије, ${ }^{16}$ предвићено је да делови Војске Србије могу бити стављени у приправност и употребљени (планирање, припремање и извођење борбене и неборбене операције) у случају проглашења ванредног стања услед природних и других несрећа и катастрофа, на основу одлуке начелника Генералштаба или надлежног старешине, а по посебном овлашћењу председника Републике. Међутим, за потребе пружања подршке цивилним властима Војска Србије не развија посебне снаге већ користи постојеће делове Војске ради заштите и спасавања људи, материјалних и културних добара од елементарних непогода, техничко-технолошких несрећа, последица тероризма и других већих несрећа, које, сходно основној намени, могу успешно извршавати те задатке. $^{17}$ Такође, доктринарним одредбама предвиђено је да Војска, за разлику од борбених операција где има водећу улогу, у неборбеним операцијама има улогу подршке осталим снагама система одбране. ${ }^{18}$ У таквим околностима успешност извођења неборбених операција, пре свега, зависи од постигнутог нивоа успостављене сарадње и координације са државним органима који руководе снагама заштите и спасавања на угроженом подручју и од степена оспособљености и опремљености јединица Војске Србије за реализацију неборбених активности.

\section{Доктрина Копнене војске}

Доктрина Копнене војске је главни доктринарни докуменат вида Копнена војска заснован на Доктрини Војске Србије, Доктрини операције и функционалним доктринама Војске Србије. Представља основу за израду правила, упутстава, тактика, техника и процедура и обучавања команди и јединица Копнене војске. Њена основна намена јесте да одговори на питање КАКО ће се команде и јединице супротставити савременим изазовима, ризицима и претњама безбедности, односно како да се обезбеди јединствени приступ и поступак у развоју способности Копнене војске за одбрану територије од оружаног угрожавања споља, учешће у одржавању и развијању мира и безбедности, са партнерским земљама, у региону и свету и пружању помоћи цивилним властима у супротстављању претњама безбедности.

Копнена војска се употребљава у миру, ратном и ванредном стању извођењем борбених и неборбених операција тактичког, оперативног и стратегијског значаја. ${ }^{20}$ Међутим,

\footnotetext{
${ }^{16}$ Исто, стр. 62.

${ }^{17}$ Исто, стр. 66.

${ }^{18}$ Исто, стр. 62.

${ }^{19}$ Исто, стр. 82.

${ }^{20}$ Доктрина Копнене војске, Медија центар „Одбрана”, Београд, 2012, стр. 64.
} 
све учесталија појава природних непогода, попут суша, поплава и земљотреса намеће потребу за употребом снага Копнене војске и у ванредним ситуацијама. Доктрином Копнене војске употреба снага у случају природних непогода, техничко-технолошких и других несрећа остварује се извођењем неборбених операција чији је основни циљ пружање подршке цивилним властима у супротстављању не војним претњама безбедности.

Пружање подршке цивилном становништву, у сарадњи са локалним властима у угроженим подручјима, снаге Копнене војске реализују кроз одређене неборбене активности. ${ }^{21}$ То су:

- евакуација становништва - активност у којој учествују снаге Копнене војске, а реализује се у случају опасности која може бити изазвана деловањем непријатеља или природне и технолошке несреће. Реализује се у сарадњи и на захтев локалних власти;

- дистрибуција основних животних намирница - активност коју реализују снаге Копнене војске у сарадњи и на захтев локалних власти. Снаге Копнене војске могу се ангажовати за транспорт хране, воде и других потребних добара, спремање и поделу оброка, као и за стварање основних услова за смештај угроженог становништва;

- обезбеђење здравствених услуга - скуп активности које реализују јединице санитетске службе ради лечења повређених и оболелих, санитетске евакуације, снабдевања медицинским потрошним средствима и ветеринарско-санитарног надзора намирница на угроженим подручјима;

- пружање помоћи у санирању последица елементарних и техничко-технолошких несрећа - различите мере и радње које зависе од врсте и природе несреће. Снаге Копнене војске могу да пружају помоћ у гашењу пожара, изградњи насипа на поплављеним подручјима, уклањању одрона, поправци и одржавању путева, прикупљању података и уклањању последица у хемијским акцидентима.

Успешна реализација додељених задатака у неборбеним операцијама приликом пружања подршке цивилним властима, јединице Копнене војске, према доктринарним решењима, ${ }^{22}$ остварује се, пре свега, кроз правовремену идентификацију неоружане претње, ефикасном употребом снага на смањивању утицаја претње и спровођењем активности на санирању последица претње.

Идентификовање неоружане претње подразумева њено откривање и процену деловања. Прикупљањем информација и разменом информација са цивилним структурама власти омогућава се визуелизација ситуације на терену и услова оперативног окружења. ${ }^{23}$

Смањење утицаја претње подразумева стварање услова за успешну реализацију планираних активности снага Копнене војске у току пружања подршке цивилним властима за време елементарних непогода, индустријских и других несрећа и епидемија. Остварује се: прецизирањем елемената координације са цивилним структурама, довођењем снага Копнене војске у угрожену зону, заштитом снага, логистичком подршком снага и другим задацима којима се стварају повољни услови за постизање жељених ефеката. ${ }^{24}$

\footnotetext{
${ }^{21}$ Исто, стр. 71

${ }^{22}$ Исто, стр. 68.

${ }^{23}$ Исто, стр. 68.

${ }^{24}$ Исто, стр. 68.
} 
Активности на отклањању последица претње представљају одлучујући задатак снага Копнене војске у неборбеним операцијама. Остварују се одлучујућим неборбеним активностима снага Копнене војске у току извођења операције и фазе стабилизације попут: пружање помоћи цивилним структурама у току евакуације становништва, дистрибуцији помоћи, изолацији угрожене зоне, збрињавања повређених и оболелих, асанацији угрожене зоне, гашења пожара, транспорта, изградњи насипа, обнављање инфраструктуре и других задатака који су прецизирани елементима координације између ангажованих снага КоB-а и цивилних структура. ${ }^{25}$

\section{Доктрина операција Војске Србије}

Основни доктринарни докуменат којим се утврђују општа опредељења и основни ставови о операцијама ВС у миру, ванредном и ратном стању јесте Доктрина операција Војске Србије. Намењена је командама, јединицама и установама Војске Србије, као и свим другим субјектима у систему одбране.

У документу се, на основу карактеристика безбедносног окружења, фризиономије оружаних сукоба, дефинисаних мисија и задатака Војске Србије, карактера и садржаја савремених војних доктрина и достигнутог степена развоја Војске Србије операција десринише као „скуп борбених и/или неборбених активности, покрета и других акција, које се предузимају по јединственој замисли ради остваривања општег циља различитог значаја. Изводе се самостално, у сарадњи са другим снагама одбране, снагама земаља партнера и снагама савезника". ${ }^{26}$ Такође, даље се дефринише као „сложен, планиран и припремљен процес, у којем се расположивим ресурсима за одређено време и јединственој замисли остварују циљеви различитог значаја". ${ }^{27}$ Операције, као облик планирања, припреме и извођења борбених дејстава, без обзира на различите борбене и неборбене активности у употреби војних снага, у начелу имају следеће фазе: припрему, извођење и стабилизацију и дезангажовање. $^{28}$

Операције у којима се тежишно изводе неборбене активности као подршка остварењу мисије аутори Доктрине сврставају у неборбене. а када говоре о појму операције подршке цивилним властима у супротстављању неоружаним претњама безбедности кажу да се: „изводе у случају природних непогода, индустријских и других несрећа и епидемија. Циљ извођења операција је подршка цивилним властима и становништву ради заштите и спасавања живота људи, материјалних добара и животне средине. За успех у извођењу операција потребни су: непосредна сарадња и координација с државним органима који руководе свим снагама на угроженом подручју и употреба потпуно оспособљених и опремљених јединица Војске Србије".

\footnotetext{
${ }^{25}$ Исто, стр. 68.

${ }^{26}$ Доктрина операције Војске Србије, Медија центар „ Одбрана”, Београд, 2012, стр. 32.

${ }^{27}$ Исто, стр. 32.

${ }^{28}$ Исто, стр. 53.

${ }^{29}$ Исто, стр. 37
} 


\section{Речна фрлотила}

Специфичност Речне флотиле у односу на остале снаге система одбране је њена везаност за акваторију и приобаље у току извршавања највећег броја додељених мисија и задатака. Задатак „Помоћ цивилним властима у случају природних непогода, техничко-технолошких и других несрећа" Речна фрлотила реализује кроз планиране и организоване активности на лоцирању и спасавању људи и животиња, евакуацији становништва и покретних ствари у безбедне зоне, дистрибуцији помоћи, изолацији угрожене зоне, збрињавању повређених и оболелих, пружању медицинске помоћи, гашењу пожара, транспорту, изградњи насипа, обезбеђењу важних хидро- навигацијских објеката, обнављању инфраструктуре и другим активностима на отклањању последица у конкретној ванредној ситуацији.

\section{Појам, намена и задаци}

Речна фрлотила је јединица Копнене војске која интегрише у функционалну целину речне јединице и инжињеријске јединице ради извршења додељених мисија и задатака на и у захвату унутрашњих пловних путева Републике Србије. Задатке извршава самостално или у оквиру операција КоВ-а и осталих снага система одбране.

Намена Речне фрлотиле проистиче из захтева и способности за извршење мисија и задатака дефинисаних Доктрином Војске Србије који су условљени специфичним војногеографским карактеристикама унутрашњих пловних путева (у даљем тексту УПП) у оквиру ратишта Републике Србије. Данас је евидентан друштвени, економски и безбедносни значај УПП, а са тим и улога Речне фрлотиле да у садејству са осталим јединицама КоВ-а штити интересе Републике Србије на унутрашњим пловним путевима. ${ }^{30}$

Може се закључити да је основна намена Речне фрлотиле да развија и унапређује оперативне способности за извођење операција на и у захвату УПП и другим текућим и стајаћим водама, у свим хидролошким и метеоролошким условима, самостално или у садејству са јединицама КоВ-а и осталим снагама система одбране, као подршка додељеним мисијама Војске Србије.

Основни - наменски задаци за које се команда и потчињене јединице оспособљавају и увежбавају, а у вези с извршавањем задатака из све три мисије Војске Србије, јесу $^{31}$ : одбрана унутрашњих пловних путева, подршка снагама КоВ-а и осталим снагама система одбране на и у захвату река, канала и језера и задатак трагања и спасавања на рекама, каналима и језерима. Међутим, све чешћа појава елементарних непогода и проглашавање ванредне ситуације на територији општина у зони одговорности Речне флотиле, односно у захвату УПП узроковало је све значајнију употребу Речне фрлотиле у реализацији задатака трагања и спасавања.

\footnotetext{
${ }^{30}$ Комљеновић, С.: Метеоролошко обезбеђење припреме одбрамбене операције Речних јединица, магистарски рад, ВА ВС, Београд, 2015, стр. 38.

${ }^{31}$ Исто, стр. 28-34.
} 
Речна флотила у ванредним ситуацијама, а нарочито када је реч о угрожавању становништва и материјалних добара услед деловања поплавног таласа, због своје специфичности, има значајну улогу у спречавању, ублажавању и отклањању последица природних непогода.

\section{Стечена искуства из употребе Речне фрлотиле у ванредним ситуацијама}

Речна фрлотила заузима веома важно место у борби против природних непогода, а нарочито када је реч о природним непогодама изазваним поплавним таласом у захвату унутрашњих пловних путева Републике Србије. Током употребе јединица Речне фрлотиле у ванредним ситуацијама највише искуства стечено је кроз реализацију следећих задатака: евакуације становништва, материјалних добара и стоке из подручја угрожених поплавама првенствено воденим, а делимично и копненим путем; дистрибуције помоћи; изолације угрожене зоне; збрињавања повређених и оболелих; пружања медицинске помоћи; уздужног и попречног превожења; изградње насипа; изградње мосног места прелаза преко река; обезбеђења важних хидронавигацијских објеката на унутрашњим пловним путевима; обнављања инфраструктуре и других активности у конкретној ванредној ситуацији.

Међутим, поред евидентних успеха, уочени су и одређени недостаци приликом заједничког ангажовања јединица Речне флотиле са осталим носиоцима заштите и спасавања, а који се, углавном огледају кроз:

- непостојање заједничког планирања, на нивоу система заштите и спасавања Републике Србије,

- не координираност захтева општинских, окружних, покрајинског и републичког штаба за ванредне ситуације,

- недовољно ангажовање представника штабова за ванредне ситуације на локацијама ангажовања снага заштите и спасавања и лошу координацију активности на терену,

- спор проток информација до последњег субјекта на терену,

- слабу и непотпуну визуализацију ситуације са терена,

- не обезбеђење смештаја, исхране, горива и мазива од стране локалне самоуправе за ангажоване ресурсе Министарства одбране и Војске Србије,

- непотпуну обученост официра за везу у штабовима за ванредне ситуације на свим нивоима командовања,

- нерасположивост инжињеријских машина за задатке заштите и спасавања, специјалних наменских алатки за чишћење снега, акумулатора, додатака за комбиноване грађевинске машине (ЈЦВ), потрошних и резервних делова из надлежности лаког ремонта за хитне оправке инжињеријских машина, дотрајалости ресурса и других проблема везаних за материјално обезбеђење,

- ограничену расположивост вучних возова за транспорт инжињеријских машина од мирнодопских локација до локација ангажовања и

- нерасположивост и недоступност руковаоца инжињеријских машина, односно немогућност ангажовања дуплих посада. 
Наведени недостаци су занемарљиви у односу на постигнуте ефекте. Међутим, не треба их игнорисати већ напротив - детаљно анализирати, извући поуке и, на основу добијених закључака, предузети одговарајуће мере за њихово отклањање а идентификоване недостатке користити приликом доградње оперативних способности Речне фрлотиле за њену даљу употребу у ванредним ситуацијама.

\section{Мере за изградњу оперативних способности речне фрлотиле за употребу у ванредним ситуацијама}

Савремени безбедносни изазови, ризици и претње, попут елементарних непогода и техничко-технолошких и других несрећа, све чешћи су разлози за увођење ванредне ситуације на територији Републике Србије чијим проглашењем држава активира додатне снаге и средства ради заштите и спасавања људи, материјалних добара и животне средине.

Немогућност спречавања, ублажавања и отклањања последица услед деловања наведених опасности редовним функционисањем система основни је разлог због којег је Војска Србије, као додатна снага заштите и спасавања, била ангажована у ванредним ситуацијама. Речна фолотила, као саставни део Војске Србије, такође је дала значајан допринос у реализацији задатака из треће мисије Војске Србије, с тим да стечена искуства указују на потребу даљег развоја оперативних способности чију изградњу и унапређење треба планирати преко чинилаца развоја, као што су: доктрина, организација, обука, опремање и финансирање Речне флотиле.

\section{Доктрина}

Војна доктрина је највиши програм развоја војне делатности у миру и рату. Она свакој војсци обезбеђује заједнички језик, филозофију, сврху и јединство деловања. Представља скуп утврђених и усвојених ставова и погледа на организацију, припрему и употребу војске у миру, ратном и ванредном стању. Може се рећи да је доктрина један од кључних чинилаца развоја оперативних способности ${ }^{32}$ на основу којих се јединице припремају и ангажују у све три мисије Војске Србије. Међутим, када је реч о њеном односу према Речној флотили, потребно је конкретизовати доктринарне ставове и опредељења о месту и улози Речне фрлотиле у извршавању треће мисије Војске Србије. Заокруживањем система доктринарних докумената до најнижег нивоа општости, кроз правила, приручнике и упутства обезбедиле би се неопходне смернице за припрему и употребу речних, ронилачких и понтонирских јединица у различитим специфичним ситуацијама. Уградњом нових решења и стечених искустава током ангажовања јединица у ванредним ситуацијама постигла би се свеобухватнија и правовремена употреба јединица у условима где Војска Србије није носилац активности на угроженом подручју већ искључиво подршка цивилним органима у супротстављању претњама безбедности.

\footnotetext{
${ }^{32}$ О утицају доктрине на оперативне способности видети више у раду: Форца, Б.: „Условљеност изградње оперативних способности од развоја доктрине Војске Србије”, Војно дело, Медија центар „Одбрана", YU ISSN 0042-8426, Београд, 2014, стр. 210-223.
} 
Такође, даљим развојем доктринарних решења, уважавајући тренутну законску регулативу која се односи на ванредне ситуације, избегле би се недоумице и дилеме приликом употребе Речне фротиле током координираног деловања са осталим снагама система заштите и спасавања у Републици Србији. Наиме, приликом употребе јединица Војске Србије у ванредним ситуацијама, новим доктринарним ставовима требало би се јасно и прецизно дефинисати када и у којим случајевима се јединице Војске Србије могу употребити, а да се при томе не нарушава начело поступности, што је до сада у пракси био чест случај. Начело поступности десринисано је чланом 12. Закона о ванредним ситуацијама и предвиђа да: „(...) када друге снаге и средства система заштите и спасавања нису довољни за заштиту и спасавање људи, материјалних и културних добара и животне средине од катастрофа изазваних утицајем елементарних непогода и других несрећа, на захтев Министарства - организационе јединице надлежне за ванредне ситуације (...) Министарство одбране обезбеђује учешће организационих делова Министарства одбране, команди, јединица и установа Војске Србије за пружање помоћи у заштити и спасавању, у складу са законом." ${ }^{33}$ Уважавањем начела поступности спречила би се непланска и неекономична употреба људи и средстава Војске Србије, односно спречило би се њено неоправдано ангажовање у ситуацијама када регуларне снаге и субјекти система заштите и спасавања могу самостално да се одбране од угрожавајуће појаве без ангажовања додатних снага и средстава.

Затим, неопходно је десинисати јасна и прецизна начела командовања и руковођења нашим јединицама у ванредним ситуацијама. У Закону о ванредним ситуацијама командовање и руковођење је регулисано на следећи начин: „Када у заштити и спасавању учествују јединице Војске Србије, њима командују њихове надлежне старешине, у складу са одлукама штаба за ванредне ситуације који руководи и координира заштитом и спасавањем." ${ }^{34}$ Међутим, непостојање заједничког планирања употребе свих учесника у ванредним ситуацијама, не координирани захтеви општинских, окружних, покрајинског и републичког штаба за ванредне ситуације, спор проток информација до последњег субјекта на терену и обрнуто, као и непотпуна визуализација ситуације, јесу фактори који су отежавали командовање и руковођење нашим јединицама у ванредним ситуацијама. Успешност система командовања и руковођења требало би да се обезбеди, пре свега, свеобухватним сагледавањем и уважавањем специфичности ангажовања јединица у неборбеним операцијама, добром комуникацијом са представницима цивилне власти, квалитетним и

\footnotetext{
${ }^{33}$ Закон о ванредним ситуацијама, Службени гласник РС, број 111/2009 и 92/2011, члан 12.

${ }^{34}$ За координацију и руковођење заштитом и спасавањем у ванредним ситуацијама у складу са Закон о ванредним ситуацијама, као оперативно-стручна тела формирају се штабови за ванредне ситуације, према следећем:

- за територију Републике Србије - Републички штаб за ванредне ситуације, који формир Влада;

- за територију аутономне покрајине - покрајински штаб за ванредне ситуације, који формира извршни орган аутономне покрајине;

- за територију управног округа - окружни штаб за ванредне ситуације, који формира Републички штаб за ванредне ситуације;

- за територију града - градски штаб за ванредне ситуације, који формира скупштина града;

- за територију општине - општински штаб за ванредне ситуације, који формира скупштина општине.

Штаб чине командант, начелник и чланови штаба, а у градском и општинском штабу и заменик команданта штаба. Руковођење штабом поверено је носиоцу власти на одговарајућем нивоу. У састав штаба улазе и представници ВСв, најчешће представници територијално надлежне јединице ВС који учествују у раду штаба.
} 
правовременим информацијама са терена, потпуним разумевањем додељених задатака и ефеката које команданти треба да постигну, као и максималном слободом акције којом би располагали приликом употребе јединица Речне фрлотиле.

\section{Организација}

Доктринарним решењима снаге Речне флотиле, због своје специфичности, могу се организовати у снаге чија је употреба од пресудног значаја за цивилне власти током елементарних непогода. У ванредним ситуацијама, насталим као последица елементарних непогода, Речна фрлотила своје снаге начелно организује у снаге за реаговање на угрожавајућу појаву и снаге за отклањање насталих последица. Генерисање снага, у зависности од природе задатка, врши се од професионалних, специјално опремљених, врхунски обучених припадника из састава јединица са високим степеном развијености. Такве јединице у Речној флотили су речне и ронилачке јединице намењене за контролу унутрашњих пловних путева и службу трагања и спасавања. Међутим, за реализацију неборбених активности током ванредне ситуације у којој се ангажују инжињеријско-понтонирске јединице захтевају се одређене организацијске промене. Пре свега, потребно је подићи ниво развијености понтонирских батаљона, а затим декларисати бар једну понтонирску чету за пружање подршке цивилним властима у супротстављању не војним претњама безбедности. На тај начин обезбедила би се правовремена употреба снага за реаговање и отклањање последица, односно постигла би се потребна способност за правовремено и ефикасно деловање понтонирских јединица у ванредним ситуацијама.

Такође, искуства стечена приликом ангажовања ронилачких јединица током мајских поплава 2014. године указују на потребу спровођења одговарајућих организацијских промена када је реч и о ронилачким јединицама. Наиме, две ронилачке јединице, једна распоређена у специјалној бригади и друга у РФ, морале би да се обједине у јединицу ранга батаљона. Формирањем ронилачке јединице ранга батаљона спречила би се тренутна диверзификација људских и материјалних ресурса, односно обезбедила би се већа расположивост са специјално обученим људством, ронилачком опремом, специјалним м/в, гуменим чамцима са ванбродским моторима, рекомпресионим коморама и другим елементима неопходним за успешну реализацију рискантних ронилачких задатка. Такође, процес доношења одлука приликом планирања употребе ронилачких јединица у војним операцијама, поред осталог и у ванредним ситуацијама, због стручности припадника команде батаљона састављеног искључиво од старешина ронилачке специјалности, био би знатно ефикаснији и јефтинији.

\section{Опремање}

Крајње жељено стање када је реч о извођењу операција пружање помоћи цивилним властима у ванредним ситуацијама јесте да се снаге Речне флотиле на што ефикаснији и ефективнији начин супротставе наилазећој претњи са циљем да се последице по човека, животну средину и друштво у целини максимално ублаже. Затим, да се након фазе реаговања на новонасталу ситуацију, у најкраћем периоду, обезбе- 
де услови за нормалан живот и самостално функционисање цивилних структура власти, а да за то није потребно ангажовање додатних снага заштите и спасавања.

Успешност наведене операције, поред непосредне сарадње и координације с државним органима и потпуне оспособљеност припадника Речне фрлотиле, исто тако, зависи и од степена попуњености и опремљености са савременим средствима и опремом за реализацију задатака заштите и спасавања. У том контексту, када је реч о Речној фрлотили Војске Србије, потребно је предузети мере како би се њени припадници опремили средствима која би обезбедила велику покретљивост на угроженом подручју, успешност у реализацији задатака трагања и спасавања и безбедно извршавање свих активности у условима ванредне ситуације. Тако, на пример, ронилачке јединице, поред постојеће опреме, требало би опремити и одређеним средствима, као што су:

- специјална одела за трагање и спасавање, такозвана триламинатна одела која би спасиоцима обезбедила лаку уочљивост у условима слабе видљивости, потпуну заштиту од дејства контаминираних вода и повољну микроклиму унутар одела због дужег коришћења у различитим метеоролошким условима, чиме би се дефинитивно повећале могућности извршења задатка трагања и спасавања,

- савремена ручна GPS,

- ефикаснија преносна средства везе,

- ручне светлосне лампе са великом аутономијом,

- савремени сонари за претраживање речног дна,

- типски спасилачки чамци који би обезбедили успешно трагање и спасавање и безбедну евакуацију становништва,

- ронилачка опрема за роњење на великим дубинама и у врло тешким условима и

- опрема за вађење потонулих предмета на површину, односно ронилачки лифтови и цилиндри.

Слична ситуација је и у пловним јединицама, чије оперативне способности за извршење задатка из треће мисије могу да се унапреде набавком опреме која обухвата:

- савремене навигацијске инфрормационе системе,

- адекватне радаре и дубиномере за пловидбу у условима смањене видљивости и у отежаним хидронавигацијским условима пловидбе,

- камере високе резолуције,

- IC камере и

- лучке пловне дизалице велике носивости намењене за тешке радове на УПП Републике Србије.

У фази отклањања последица насталих услед деловања угрожавајуће појаве најзначајнију улогу имају инжињеријско-понтонирске јединице. Међутим, успешност извршавања ове фразе умногоме зависи од располагања и доступности савременим и модерним инжињеријским средствима попут:

- средстава која ће да обезбеде велику покретљивост преко сувих и водених препрека коришћењем различитих врста јуришних, понтонских и лансирних мостова,

- средстава за савлађивање слабо носивог тла,

- средстава за побољшање проходности преко оштећених и порушених делова путева,

- средстава за ојачавање природних и вештачких препрека и

- савремених грађевинских машина за санирање путне инфраструктуре и рашчишћавање терена. 
Може се закључити да се унапређењем оперативних способности јединица Речне фрлотиле преко чиниоца развоја, у овом случају опремањем савременим средствима и опремом, обезбеђује успешност у реализацији задатка пружања подршке цивилним властима у случају природних непогода, техничко-технолошких и других несрећа. Студије и пројекти даље модернизације и опремања јединица Речне фрлотиле, поред одбрамбених потреба, треба да уваже потребе и стечена искуства током ангажовања јединица на спречавању и отклањању последица од не војних претњи.

\section{Обука}

У Доктрини Војске Србије наводи се да: „Обука за пружање помоћи цивилним властима у супротстављању претњама безбедности изводи се у оквиру редовне обуке и оспособљавања, (...)", 35 што значи да се снаге одређене за извршавање задатака заштите и спасавања обучавају у оквиру редовне индивидуалне и колективне обуке, а у складу са додељеном мисијом и одобреном листом тежишних задатака. Јединице које добију мисију да са делом снага извршавају задатке из области помоћи цивилним властима на отклањању последица елементарних непогода и техничко-технолошких несрећа, одређују део снага за ту намену чију обуку планирају у складу са проценом обучености команданта којима су, за извршење, додељени задаци из треће мисије Војске Србије. На основу добијене мисије и израђене листе тежишних задатака, ${ }^{36}$ а у складу са проценом обучености планира се обука за текући оперативни циклус.

Дакле, обуком, као једним од чинилаца развоја оперативних способности, надокнађује се јаз између потребног и тренутног степена обучености команди и јединица за извршавање додељених задатака. Обука обично прати развој доктрине, наоружања и војне опреме и у њиховој је фрунцции. Она није сврха и циљ самој себи, већ алат који нам омогућава унапређење способности. У оквиру процеса обучавања постоји највише простора за унапређење способности Војске Србије за реализацију задатака заштите и спасавања током ванредних ситуацијама. Кроз обуку је могуће оспособити појединце за допунске специјалности, јединице за сарадњу са осталим снагама заштите и спасавања, команде за заједничко планирање употребе снага Војске Србије на задацима заштите и спасавања, официре за везу за рад у штабовима за ванредне ситуације и многе друге.

Заједничко планирање употребе свих снага заштите и спасавања Републике Србије, под руководством надлежне институције је један од главних проблема са којим су се актери сусретали током ангажовања у ванредним ситуацијама. Уочен проблем је могуће превазићи реализацијом семинара, радионица, зборова, студијских путовања и сличним облицима заједничког обучавања на којима би, пре свега, учествовали представници Војске Србије, Сектора за ванредне ситуације, јединица

\footnotetext{
${ }^{35}$ Доктрина Војске Србије, Медија центар „Одбрана”, Београд, 2010, стр. 21.

36 Представља скуп заједничких задатака од највеће важности за додељену мисију који морају бити успешно реализовани у складу са стандардима и процедурама. Упутство за управљање обуком у Копненој војсци, Команда КоВ-а, Ниш, 2010, стр. 29.
} 
цивилне заштите, Црвеног крста, Горске службе, хидрометеоролошких служби и других субјеката заштите и спасавања. У садржај интегрисане обуке, поред тема из области заједничког планирања операција, потребно је уврстити и практичне облике обучавања по угледу на реализовану заједничку вежбу под називом „РЕКА 2012 "37. На вежби су у свим фазама извођења, поред јединица Речне флотиле, учествовали и представници Сектора за ванредне ситуације, Горске службе спасавања и Црвеног крста Републике Србије. Оваквим видом заједничког обучавања отварају се нове перспективе и идеје приликом решавања различитих изазова и проблема, спречава се дуплирање капацитета и, на крају, учесници вежби се међусобно упознају са радом и могућностима других субјеката заштите и спасавања.

\section{Финансирање}

Финансирање ангажованих снага заштите и спасавања је у надлежности оних који их ангажују. Законом о ванредним ситуацијама прецизирано је да: „Штабови за ванредне ситуације, који ангажују снаге заштите и спасавања су одговорни и за финансирање активности заштите и спасавања, односно плаћање трошкова ангажованих снага". ${ }^{38}$ То се у пракси није применило. Када анализирамо употребу снага Министарства одбране и Војске Србије на задацима помоћи цивилним органима власти на отклањању последица од елементарних непогода у претходном периоду видећемо да је трошак ангажовања углавном пао на ангажоване снаге. То се посебно односи на снаге Министарства одбране и Војске Србије.

Осим трошкова исказаних у финансијским средствима у вези са дневницама, утрошак горива, артикала хране и слично, ангажовање ресурса МО и ВС у неборбеним операцијама узрокује и друге трошкове. Они се, пре свега, огледају у утрошку експлоатационих ресурса машина и возила ангажованих у операцији и ресурса утрошених на одржавању ангажованих машина и возила.

Како би се настали трошкови током употребе снага Војске Србије у трећој мисији у потпуности надокнадили, неопходно је предузети одговарајуће мере. Пре свега, Министарство одбране и Војска Србије требало би да израде ценовник ангажовања својих ресурса и доставе их носиоцима цивилних власти и штабовима за ванредне ситуације. Такође, кроз процес едукације и додатног оспособљавања представника Војске Србије и осталих чланова штабова за ванредне ситуације треба указати на чињеницу да употреба снага заштите и спасавања кошта и да је та обавеза искључиво у надлежности локалне самоуправе која ангажује те снаге. Органи локалне самоуправе још увек немају свест о томе да ангажовање ресурса Министарства одбране и Војске Србије није бесплатно, као ни праксу да приликом пројектовања својих годишњих буџета, поред осталог, планирају трошкове везано за евентуално ангажовања додатних снага, односно јединица Војске Србије. Израдом јединственог ценовника и инсистирањем да се свако ангажовање у ванредним ситуацијама наплати у складу са законском регулативом, дефинитивно би се избегла

\footnotetext{
${ }^{37}$ Вежба је реализована под руководством Војске Србије у октобру 2012. године на реци Тиси.

${ }^{38}$ Закон о ванредним ситуацијама, „Службени гласник РС”, бр. 111/09 и 92/11, члан 111.
} 
ситуација у којој се јединице Војске Србије користе чак и за најједноставније задатке за чију реализацију су довољне снаге локалних самоуправа. Такође, наплатом својих услуга Војска Србије избегла би додатне трошкове у виду дневница, исхране, амортизације и одржавања покретних средстава насталих током употребе сопствених снага у ванредним ситуацијама.

Чињеница да јединице Војске Србије располажу ограниченим фринансијским средствима и да свака непланска активност, која није у складу са фринансијским планом за текућу годину, може да угрози реализацију планираних пројеката битних за ту јединицу још један је разлог због којег фринансирање активности јединица у ванредним ситуацијама треба да буде реално и транспарентно.

\section{Закључак}

Претходна искуства указују на чињеницу да су ванредне ситуације проузроковане природним непогодама попут снежних падавина, земљотреса и поплава били најчешћи узрочници угрожавања опште безбедности нашег друштва. Веома важно место у борби против природних непогода, нарочито када је реч о великим поплавама, заузима Речна флотила са својим људским, материјалним и организационим капацитетима. Њен допринос се нарочито очекује у реализацији задатака попут: евакуације становништва, материјалних добара и стоке из подручја угрожених поплавама, првенствено воденим, а делимично и копненим путем; дистрибуције помоћи; изолације угрожене зоне; збрињавања повређених и оболелих; пружања медицинске помоћи; асанације угрожене зоне; гашења пожара; транспорта; изградње насипа; обезбеђења важних хидронавигацијских објеката на унутрашњим пловним путевима; обнављања инфраструктуре и других активности у конкретној ванредној ситуацији.

Међутим, правовремен, безбедан и ефикасан одговор на опасности захтева: врхунску обученост, опремљеност савременом опремом и средствима, адекватне процедуре и правила употребе јединица у различитим ситуацијама, као и уважавање важећих нормативно-правних и стратегијско-доктринарних решења. Предмет овог рада управо је био десинисање мера за унапређење оперативних способности Речне фолотиле за њену ефикасну употребу у неборбеним операцијама. Испуњењем претходно наведених захтева, пре свега, обезбеђује се организован, сигуран и систематски приступ у решавању врло сложених и динамичних задатака приликом ангажовања јединица Речне флотиле у ванредним ситуацијама. У том случају, дефинисање мера за изградњу оперативних способности преко чиниоца развоја попут: доктрине, организације, обучености, опремљености и финансирања представљају приоритет за сваку јединицу, чиме се постиже жељени потенцијал за реализацију задатака заштите и спасавања.

У раду су предложене мере које уважавају начело поступности приликом употребе снага и средстава Речне флотиле у пружању помоћи цивилним властима у ванредним ситуацијама. Затим, командовање и руковођење јединицама Војске Србије у реализацији задатака заштите и спасавања треба да уважава специфичности ванредне ситуације попут чињенице да активностима на терену руководе шта- 
бови за ванредне ситуације и да је потреба за одличном комуникацијом и координацијом са представницима цивилних органа власти од пресудног значаја. Студије и пројекти модернизације и опремања јединица Речне флотиле, поред одбрамбених потреба, треба да уваже и стечена искуства током ангажовања јединица на спречавању и отклањању последица од не војних претњи. Затим, треба практиковати заједничку обуку између свих субјеката заштите и спасавања, јер се на тај начин остварују нове перспективе и идеје приликом решавања различитих изазова и проблема, спречава се дуплирање капацитета и, на крају, учесници интегралне обуке се међусобно упознају са радом и могућностима других субјеката заштите и спасавања. Такође, предложеним мерама у виду израде јединственог ценовника и наплатом ангажовања јединица Војске Србије, у складу са законским одредбама, током ванредне ситуације избегли би се додатни трошкови и беспотребна ангажовања на тривијалним задацима за чију реализацију су довољне снаге из састава јавних комуналних предузећа локалних самоуправа.

Наведеним мерама и уградњом позитивних решења и искустава у јединствени доктринарни систем, стечених током ангажовања јединица Војске Србије у ванредним ситуацијама, дефинитивно би се унапредиле оперативне способности Речне фрлотиле за њену употребу у неборбеним операцијама. Међутим, реализација заштите и спасавања је сложен и захтеван процес који је, поред предвидљивих и мерљивих чинилаца, углавном, праћен неизвесним, динамичним и комплексним појавама. Због тога је неопходно наставити са даљим истраживањем у овој области, како би се обезбедила још већа ефикасност, универзалност и флексибилност приликом ангажовања јединица Речне флотиле у ванредним ситуацијама.

\section{Лumepamypa}

[1] Аврамовић, Д. и Млађан, Д.: „Ванредно стање и ванредна ситуација - компаративни терминолошки и садржински аспекти ", Теме - часопис за друштвене науке, Универзитет у Нишу, број 2, 2014.

[2] Byrne, B. with Baden, S.: Gender, emergencies and humanitarian assistance, report commissioned by the WID Desk, European Commission, Directorate General for Development, Brussels, 1995.

[3] Војни лексикон, Војноиздавачки завод, Београд, 1981.

[4] Вујаклија М.: Лексикон страних речи и израза, Просвета, Београд, 1980.

[5] Доктрина Војске Србије, Медија центар „Одбрана”, Београд, 2010.

[6] Доктрина КоВ, Медија центар „Одбрана”, Београд, 2012.

[7] Доктрина операција, Медија центар „Одбрана”, Београд, 2012.

[8] Закон о ванредним ситуацијама, Службени гласник PC, број 111/2009 и 92/2011.

[9] Калюжный, Е. А., Михайлова, С. В., Напреев, С. Г. \& Маслова, В. Ю.: Безопасность изнедеятельности, АГПИ, Арзамас, 2012.

[10] Karović, S., Slavković, R. i Komazec, N.: „Crisis management in defence and emergencies", Conference proceedings of the International Scientific Conference, LIPTOVSKY MIKULÁŠ, 24. - 26. septembra 2014.

[11] Комљеновић, С.,: Метеоролошко обезбеђење припреме одбрамбене операције Речних јединица, магистарски рад, ВА ВС, Београд, 2015. 
[12] Мастрјуков, Б. С.: Безопасность в чрезвичайных ситуациях, Издательский центр Ацадемиа, Москва, 2004

[13] Млађан, Д. и Кекић, Д.: „Ванредна ситуација - прилог концептуалном одређењу безбедности ", НБП - Журнал за криминалистику и право, бр. 3, 2007.

[14] Правило Речна фрлотила (привремено), ККоВ, Ниш, 2014.

[15] Славковић, Р., Каровић, С., Јелић, М: „Enagagement of the Serbian Armed forces in support of civil authorities in emergencies", Conference proceedings of the International Scientific Conference, LIPTOVSKÝ MIKULÁŚ, 24. - 26. septembra 2014.

[16] Стојановић, Р.: Заштита и спасавање људи и материјалних добара у ванредним ситуацијама, Војноиздавачки завод, Београд, 1984.

[17] Устав републике Србије, Службени гласник РС, број 98/06.

[18] Упутство за управљање обуком у Копненој војсци, Команда КоВ, Ниш, 2010.

[19] Форца, Б.: „Условљеност изградње оперативних способности од развоја доктрине Војске Србије”, Војно дело, пролеће/2014, Медија центар „Одбрана”, Београд, 2014.

[20] Штрбац, К.: Ванредне ситуације, Девета школа реформе сектора безбедности, ISAC Found, Београд, 2007. 